\title{
Az európai növekedés zsákutcái
}

\section{Dead ends of the European growth}

\author{
CLAUDE ALBAGLI
}

A párizsi székhelyü Cedimes Intézet (Centre d'Études du Développement International et des Mouvements Socieaux, Nemzetközi Fejlödés és Társadalmi Mozgalmak Kutatóközpont) a nemzetközi fejlődés gazdasági és társadalmi aspektusaival foglalkozik. Kutatási területe a globalizáció, a vállalkozásfejlődés különböző aspektusainak regionális és tematikus elemzése. A Cedimes hálózatát öt kontinens 32 országában müködö egyetemek és kutatóintézetek alkotják. Az együttmüködés a különbözö gondolatok és kutatási eredmények megismerésén és terjesztésén túl az egyetemi oktatás színvonalának fejlesztését, támogatását is szolgálja. A CEDIMES Intézet müködését több forrás - tagsági díj és más bevételek, valamint állami és szponzori támogatás - biztosítja.

Tudományos céljaik érdekében az intézet évente egy tematikus nemzetközi konferenciát rendez, ahol a különböző mühelyek bemutatják az adott területen elért kutatási eredményeiket. Az elmúlt néhány év helyszíne Franciaország, Mali, Törökország, Kanada, Horvátország és Románia volt. Rendszeresen tartanak regionális, nemzeti rendezvényeket. Háromhavonta megjelenő folyóiratuk van (Cahiers de Cedimes) valamint évente egykét kiadványkötetet publikálnak (Mouvements Économiques et Sociaux - MEC). Az oktatás eredményességét doktori iskolájuk (Algériában és Párizsban), szakmai gyakorlati programjuk (többek között Kínában és az Egyesült Államokban) és évente kiosztott díj szolgálja, amellyel a legjobb külföldi és francia diákok szakdolgozatát, illetve doktori értekezésétjutalmazzák.

A Cedimes elnöke, a hálózat létrehozója Claude Albagli, aki közgazdász, egyetemi tanár, több fejlődés-gazdaságtani mü szerzője. A 2011-ben megrendezett izmiri Európai Napok címet viselö nemzeti konferencián elhangzott vitainditóját közöljük az a lábbiakban.

Napjaink nagy kérdése: hogyan lehet növelni a foglalkoztatást? A válasz egyértelmü: a növekedés által. Az ebben a témában folyó európai vita igen tanulságos. A kérdés felvetését már a 2000-es Lisszaboni stratégia tartalmazta, amely azt tűzte ki célul, hogy az Európai Unió 2015-re a világ legversenyképesebb régiójává váljon. Hamarosan, még a válság beköszönte előtt nyilvánvalóvá lett, hogy ez a cél elérhetetlen, az Európai Unió a '90-es évek óta a legalacsonyabb regionális növekedési ütemet produkálja. Ugyanakkor Európa megpróbálta

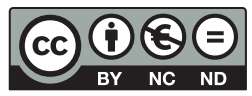


megőrizni szociális ellátási modelljét, mégpedig úgy, hogy ne kelljen elviselhetetlen terhet raknia polgáraira. Ennek érdekében hitelekhez folyamodott, ezáltal ugyan átmenetileg a folyamat kevésbé lett fájdalmas, de az eladósodás terheinek rendezése későbbi időkre halasztódott. Célszerünek látszott külső pénzügyi piacokhoz fordulni, hogy a hitelek ne csapolják meg a belső megtakarításokat és ne csökkentsék a befektetési kapacitást. Azonban ezáltal az egyes országok kiszolgáltatottá váltak a nemzetközi pénzügyi piacoknak, amelyek az államok visszafizetési képességét mérlegelve határozzák meg a kölcsönök kondícióit. Úgy tűnt, hogy az euró létrehozása biztonságot jelent az egyes országok esetleges sérülékenységének csökkentésére. A Maastrichti szerződés óvatossági szabályokat vezetett be, de a körülmények egyre inkább indokolták az attól való eltérést, és ez sorozatos pénzügyi túllépést vont maga után. Hamarosan az európai országok nagy része nem tartotta be az eladósodási küszöböt, sem a költségvetési korlátot, bár ígérték, hogy visszatérnek hozzájuk a legrövidebb időn belül. Európa nemcsak növekedési válságba került, de nem rendelkezett cselekvési lehetőséggel sem a szociális ellátás finanszírozásának folytatására. A helyzet rendezése elsődleges és sürgős igénnyé vált. De mit kellene tenni?

Két elméleti modell állt a kormányok rendelkezésére a helyzet kezelésére: a neoklasszikus és a neo-keynesiánus modell. Egyik is, másik is hozott már eredményeket, a körülmények függvényében. Mit javasolnak ezek a modellek?

A neoklasszikus elméletek szerint a lehető leghamarabb vissza kell térni a költségvetési, pénzügyi és kereskedelmi egyensúlyhoz. Ennek megfelelően az európai országoknak mindent meg kell tenniük azért, hogy rövid távon csökkentsék a költségvetés hiányát és visszaállítsák a pénzügyi egyensúlyt az eladósodás csökkentése által. Az erre szolgáló technikák elméletileg egyszerűek, azonban megvalósításuk már sokkal kényesebb: csökkenteni kell az állami kiadásokat, és növelni az adóbevételeket. A társadalmi reakciók azonban erőteljesek, a társadalom minden rétege megpróbál kitérni a megszorító intézkedések és az adóemelések elől. Ugyanakkor az intézkedések hatására csökken a kereslet, amelyet megfojt a költségvetési megszigorítás és az újabb adók sora. Ennek következtében a gazdasági tevékenység összehúzódik, ami negatívan hat a foglalkoztatásra, nehezíti a remélt pénzügyi bevételek befolyását, és végül újabb költségvetési egyensúlyhiányt okoz. Az elméleti elemzés természetesen figyelembe veszi ezt a hatást, és a költségvetési szigorhoz pénzügyi követelményt kapcsol: a leértékelést. Ennek hatására a nemzeti termelés versenyképesebb lehet a külpiacokon, a külső piaci kereslet újból beindíthatja a növekedést, és semlegesítheti a költségvetési szigor felsorolt, deflációs hatásait. Ugyanakkor e második kritériumot, amely szorosan kapcsolódik az elsőhöz, és sikerességének feltétele, nem veszik figyelembe Európában. Mi ennek az oka?

Azáltal, hogy az Európai Unió létrehozta a közös pénzt, elvette az árfolyampolitika alakításának lehetőségét az egyes országoktól. Enélkül csak a szigor marad, amelynek a gazdaságra gyakorolt depressziós hatása megakadályozza az egyensúlyok helyreállítását, és egyre újabb megszorítási terveket tesz szükséges- 
sé. Ezt erősíti, hogy az euró túl van értékelve a dollárhoz képest, amit eddig nem sikerült kiegyensúlyozni. A neoklasszikus politika megvalósítása feltételezi a nemzeti pénzügyi kontrollt, amennyiben a gazdaságok nem homogének. Ezzel az Európai Unió alapjai kérdőjeleződnek meg. Monetáris politika hiányában a szigor hatástalan, és az egyensúly megteremtésére hozott intézkedések a növekedés és a foglalkoztatás növelése terén nem érik el céljukat.

A neo-keynesiánus elméletek a kereslet növelésére alapozzák elemzésüket, ettől várják a gazdasági fellendülést és a munkanélküliség csökkenését. Alapgondolatuk, hogy a kereslet növelését célzó ráfordítások munkabér-kiáramlást okoznak, amely ösztönzi a fogyasztást, amely tovább ösztönzi a termelést, a foglalkoztatás növelését, ami újabb bérkiáramlással jár és így tovább... Azaz minden, a kereslet növelését célzó kiadás multiplikátorhatással jár az eredeti állapothoz képest. Ez a megközelítés vitathatatlanul sikeres volt 30 éven át, de jelenlegi alkalmazása új nehézségeket vet fel. Ezek közül az első az alapelvet érinti. Hogyan ajánlható egy országnak, amely a kilábalást célozza meg, költségvetési hiánya van és eladósodott, hogy újabb kötelezettségeket vállaljon? A nemzetközi pénzügyi piacok számára a már eddig is eladósodott államok hitel-visszafizetési képessége így még kockázatosabbá válik. De tételezzük fel, hogy a kormányok pedagógiai képessége és politikai ügyessége meggyőzi a piacokat a döntés megalapozottságáról! Ekkor egy kedvező folyamatnak kellene elindulnia: az volna várható, hogy a gazdaságba pumpált kereslet növekedése bérnövekedést von maga után, ami újabb keresletet kelt, és a felesleges kapacitásokkal rendelkező vállalkozások és a munkanélküliek tevékenységi, illetve munkalehetőséget találnak. Továbbá a kereslet beindulása ösztönzi a kínálatot, ami kedvező a növekedésnek, és ez a nemzeti költségvetés számára új adóbevételeket jelent. Mindez a válságból való kilábalással bíztat. De a gyakorlatban mégsem ezt figyelhetjük meg! Mi történik?

Időközben kiteljesedett a globalizáció, és a vámhatárok szinte teljesen leépültek. Ez az új gazdasági környezet az Európai Unió számára és máshol is a kínálat megváltozását eredményezte. A határok eltűnésével a kereslet nagy részét már importból elégítik ki. A feltörekvő országok olcsóbb termelése lehetővé teszi vásárlóerejük növelését. Ettől kezdve a megnövekedett kereslet már nem az adott országba irányul, hanem a külső piacok termelőihez. Jóllehet a növekedés újraindítását szolgáló intézkedéseknek az eleve megcélzott rétegek eleinte a haszonélvezői lesznek, azonban a gazdaság beindítását célzó multiplikátorhatás nem jelentkezik, mivel a kereslet a külső piacokon jelenik meg. Mindez úgy történik, mintha a feltörekvő országok exportálói speciális jutalomban részesülnének kereskedelmük intenzifikálása érdekében. Az az állam, amely ezt a stratégiát alkalmazza, elnyeri a gazdaság fellendítése érdekében megcélzott réteg megelégedését, de növekedési és foglalkoztatási céljait nem tudja teljesíteni, sőt költségvetési deficitje és eladósodottsága növekszik. A dilemma megoldása érdekében meg kellene kérdőjelezni a globalizáció egész folyamatát és a szabad kereskedelem jótékony hatásába vetett hitet. Ez egyúttal a vámhatárok megszüntetésének megkérdőjelezését is jelentené. 
Tehát, a két idézett elmélet által nyújtott közgazdasági eszközök nem képesek jó választ adni a problémára, amelynek megoldására fel kívánják használni őket. A sikertelenség oka, hogy azok a feltételezések, amelyek az elméletek környezetére vonatkoztak, már nem teljesülnek. A környezet két lényeges ponton megváltozott: egyrészt az európai nemzeti pénzügyi kontroll, másrészt a határok ellenőrzése tekintetében. Ezzel magyarázható, hogy az egyik vagy másik iskolára hivatkozó kísérletek nem voltak képesek hozni a várt eredményeket. Mi hát a megoldás? Hogyan lehetne elérni a kellő növekedést, amely végre beindítaná a foglalkoztatást?

Várható, hogy új, a korábbiakat helyettesítő elméleti megoldás hiányában a válság rövid határidőn belül nem lesz megoldható. Ehelyett olyan gyakorlati kezdeményezések láttak napvilágot, amelyek nem érintik az európai építményt és a globalizációt. A javasolt intézkedések kéttípusúak, elkerülik a monetáris kérdés felvetését és a határokét is: fő jellemzőjük, hogy az innováció-képzés-párosra, illetve a munka költségének csökkentésére irányulnak.

Az innováció szükséges a technológiai haladáshoz, a versenyképes termeléshez és az ipari szerkezet átalakításhoz. Azonban az adott problémát tekintve ez a javaslat több hátrányos tulajdonsággal rendelkezik, amelyet általában nem vernek nagydobra. Ahhoz, hogy a kutatást és a képzést előmozdító kiadások gyümölcsöző eredményt hozzanak ipari alkalmazásuk által, hosszabb időre van szükség. Amennyiben az innováció a választott megoldás, tudható, hogy nem lesz képes gyors választ adni a kihívásokra, vagyis pótolni a leértékelést vagy biztosítani a külső piacra lépést. Egyébként az innovációhoz folyamodást sokan úgy értelmezik, mint kizárólag a nyugati országok számára nyíló lehetőséget, feltételezve, hogy a feltörekvő országok megmaradnak a munkaerő-igényes iparágak vagy a lejárt technológiák alkalmazásánál. Eszerint a fejlett Európában elégséges volna megőrizni a régi előnyt. Ugyanakkor látni kell, hogy a kiváló tanulási képességű feltörekvő országok az innováció területén is beszálltak a versenybe, és alkotó kezdeményezéseik azóta kirajzottak a világba. Az innovációt egyrészt nem lehet gyarmatosítani, másrészt az innováció bevezetéséhez szükséges idő rosszul alkalmazkodik az elvárt sürgősséghez.

A munka költségének csökkentése látszik a másik alternatívának. A munka megnövekedett liberalizációja a hozzá kapcsolódó terhek csökkenésével jár, ami lehetővé tenné a nemzetközi színtéren a versenyképesség növelését. A munkanélküliség is deflációs nyomást gyakorol a munka költségeire. A piac növekvő liberalizációja és rugalmassága csökkenti vagy akár el is tünteti a szakmák között kialakult jövedelmek szabályozott különbségeit. Az ilyen intézkedés ugyan logikus, de társadalmi szinten erős ellenállást vált ki, ami megakadályozhatja a foglalkoztatottak jövedelmének csökkentését. Az ideális az volna, ha ezzel párhuzamosan csökkentenék az árakat is a vásárlóerő megőrzése érdekében: befagyasztanák az üzemanyagárakat, szabályoznák a lakbéreket, a nagykereskedelem haszonkulcsát. Ez a deflációs politika, amelynek célja tehát a jövedelmek és az árak egyidejü csökkentése lenne. A megvalósítása általában kiegyensúlyozatlan, a bérekre és ellátásokra 
vonatkozó akciók könnyebben valósíthatóak meg, mint az árak visszafogása. Franciaországban a vendéglátásban történt a közelmúltban ilyen sikertelen kísérlet. Ezelőtt utoljára 1935-ben próbált Pierre Laval kormánya deflációs politikát megvalósítani. Az intézkedések egyensúlyhiánya a következő évtől a Népfront lázadásához vezetett.

Látható, hogy az új pénz- és vámügyi környezetben a közgazdasági elméletek gyenge segítséget nyújtanak a politikai döntéshozóknak. Az elméleteket részlegesen felhasználva a kormányok nem tudták elérni a várt eredményeket, sem pénzpumpával a belső piacok ösztönzését, sem a fizetési mérlegek rendbetételét. A javasolt ötletek sem hozták a megoldást: az innováció holnapra halasztja azt, anélkül, hogy válaszolna a konjunktúra sürgető követelményére, a rugalmas munkaköltség pedig csak részben jelent eszközt, és képes a mindig rosszul kezelt defláció hatására szociális robbanást okozni. A neoklasszikus és neo-keynesiánus elméletek ma már nem érvényes hipotézisekre támaszkodnak. Célszerű volna más, kedvezőbb összefüggést találni a növekedés és a foglalkoztatás ösztönzési mechanizmusára. Ennek érdekében figyelembe kell venni a kereskedelem világméretü liberalizációjának és a heterogén európai építmény következményeit, de oly módon, hogy az elemzést ne lehessen azzal vádolni, hogy az elszigetelődést támogatja, vagy az EU sírásója lenne. Az átjárható és a szigorúan ellenőrzött határok között van egy „rés”, amelyet sürgősen meg kellene kutatni, annak érdekében, hogy a gazdaság újra lendületbe jöjjön, különben a politikusok csak ötletelnek. Francia példa erre a tisztán hazai termékek fogyasztásának ösztönzése, olyan esetekben is, amikor az áraik biztosan magasabbak külföldi versenytársaikénál, így viszont illúzió a fogyasztóktól elvárt magatartás-változás.

Az összeállitást készitette és a vitainditó előadást fordította Bartucz Sarolta. 